portant article of Levantine commerce in the Middle Ages. The contemporary specimen of this earth in the Pharmaceutical Society's collection, he says, "can hardly be genuine"; by this we suppose he means that it is probably a British "fake" of the seventeenth century. The modern specimen he gives of the Turkish stamp which used to be the "sigillum" of the earth (now put on clay bowls), reads tîn makhtûm, "sealed earth," in Arabic (not "tini maktoum," as Mr. Hasluck prints it : $k h$ must not be confounded with $k$ !). Old specimens of this Arabic seal are figured from Belon by Mr. Hasluck; but why has he printed them all on one side? Or is this the fault of Belon?

Mr. H. R. Hall contributes "An Addition to the Senmut-Fresco" at Egyptian Thebes, which shows Minoan Cretan (Keftian) ambassadors bearing gifts to the court of Queen Hatshepsu. The addition he has found in a drawing by Robert Hay, now in the MSS. Department of the British Museum, made about the year 1837 , which shows the fresco as it was then, with additional figures, vases, and a great sword. Mr. Walters notes that the peculiar method of sealing vases in vogue at Mycenæan Sparta is paralleled by Egyptian seals of Roman times; we might carry the comparison further back, for the Egyptians always sealed vases in this way, at a period contemporary with the Spartan specimens. Here is another minor

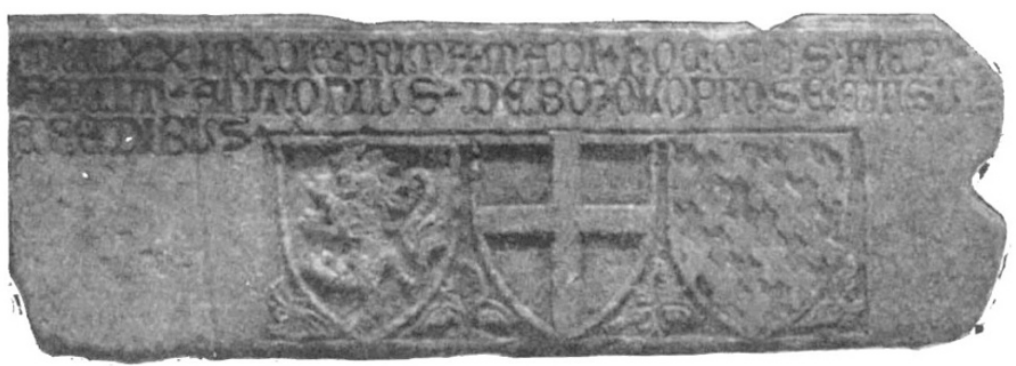

FIG. 3.-A Genoese Inscription at Chios

point of similarity between Minoan and Egyptian ways.

Prof. R. C. Bosanquet publishes the last of the old finds of the School at Præsos in Crete, in the shape of the Greek inscriptions, and Mr. Woodward contributes new material to the study of Athenian building records of the fifth century B.C. Finally, anthropology is well catered for in Mr. Wace's very interesting description of the modern survivals in North Greece of Dionysiac festivals (which have now degenerated into mere Guy Fawkes bacchanalia, accompanied by chicken-stealing and frowned upon by the police), and Mr. W. R. Halliday's critical examination of the Argive festival of the Hybristika, in connection with Herodotus's description of the marriage of the Argive

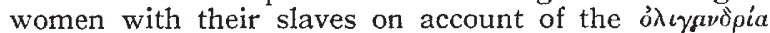
caused by the defeat of Argos by the Spartan King Kleomenes I. (Hdt. vi. 83 ). He finds the origin of this story in the festival of the Hybristika, when the slaves had full licence, and the women donned men's clothing, the men that of women. This custom of "changing 'ats" is found all over the world, as he shows, and is probably the origin of several Greek stories; for instance, he thinks, that of the Cumæan tyrant Aristodemos, who, says Plutarch, "is said to have brought up the boys of free birth to wear their hair in long tresses and to adorn themselves with gold, while he compelled the girls to have their hair cut at the level of their shoulders, and to wear cloaks like youths and little short frocks." However, this NO. 2203 , VOL. 88$]$ tale of a freakish tyrant may be a true one, and not connected with any hybristika; the pranks of Greek despots were often peculiar, and sometimes took forms of this sumptuary kind.

The frontispiece to the volume is a reproduction of a colour-photograph, by Mr. Robert Mond, of the Semnut fresco as it is to-day, which gives the most accurate possible representation of its colouring. $\mathrm{Mr}$. Mond has done a good deal for archæology by his excavations of tombs at Egyptian Thebes, and his application of the latest resource of photography to the representation of this important Egyptian fresco, and gift of the picture to the School at Athens for this volume, merit special acknowledgment.

\section{THE WASHINGTON MEETING OF THE AMERICAN ASSOCIATION.}

THE sixty-third meeting of the American Association for the Advancement of Science was held in Washington, district of Columbia, on December 27-30, Igri, under the presidency of Dr. Charles E. Bessey, professor of botany in the University of Nebraska.

The meetings began in the morning of December 27 with a meeting of the council, after which sections. and affiliated societies proceeded with business meetings and programmes of papers.

The formal opening exercises were held in the Assembly Room of the New U.S. National Museum at 9 p.m. of the same day, the exercises being preceded by a reception from 8 to $c$ o'clock. The President of the United States, Mr. Taft, was present at the opening exercises, and delivered an address of welcome, directing attention especially to the close similarity between the attitude of mind of the scientific investigator and that of the judge. Truth, in both cases, is the aim, and the judicial temperament is necessary. to the successful scientific man. The secretary of the Smithsonian Institution, Dr. Charles D. Walcott, was to have given a second address of welcome, but was absent through illness.

The president-elect, Dr. Bessey, responded to the address of welcome, and, in view of the fact that the address had been delivered by the President of the United States, took occasion to point out the importance of scientific work to Government affairs, and to urge President Taft to give all his support to scientific bureaus of the Government.

The address of the retiring president, Dr. A. A. Michelson, of the University of Chicago, was then delivered. His subject was, "Recent Progress in Spectroscopic Methods." This address was published in full in Nature of January i ith.

The meeting, as a whole, is the largest in the history of the association. The actual registration of the association proper was I402, while members of affiliated societies and others in attendance at the meetings, including very many members of the association who were unable to register, undoubtedly would have swelled the number to more than 2800 .

The addresses of the retiring vice-presidents were as follows :-Vice-President Eliakim H. Moore, before the Section of Mathematics and Astronomy, on "The Foundations of the Theory of Linear Integral Equations"; Vice-President E. B. Rosä, before the Section of Physics, on "The Work of the Electrical Division of the Bureau of Standards "; Vice-President George B. Franiforter, before the Section of Chem- 
istry, on "The Resins and their Chemical Relations to the Terpenes"; Vice-President A. L. Rotch, before the Section of Mechanical Science and Engineering, on "Aërial Engineering"; Vice-President Jacob Reighard, before the Section of Zoology, on "Adaptation" ; Vice-President R. A. Harper, before the Section of Botany, on "Some Current Conceptions of the Germ Plasm"; Vice-President R. B. Dixon, before the Section of Anthropology and Psychology, on "The Independence of the Culture of the American Indian"; Vice-President Theodore Burton, before the Section of Social and Economic Science, on "The Cause of High Prices"; Vice-President F. G. Novy, before the Section of Physiology and Experimental Medicine, on "Carriers of Disease"; Vice-President A. Ross Hill, before the Section of Education, on "The Teaching of General Courses in Science." fOwing to the death of Vice-President Christopher W. Hall, of the Section of Geology and Geography, no address was delivered before that section.)

The meeting showed, as in other recent years, an increased number of affiliated scientific societies of national scope, and was marked by the presence of the strong group of societies of economic character, including the American Economic Association, the American Statistical Association, the American Association for Labour Legislation, the American Sociological Society, and the American Home Economics Association.

As has been the growing tendency in the association, several important symposia were held, and a number of meetings of interest to several sections and societies. Among these may be mentioned a symposium relating to safety in mines; one on aërodynamics, and another on good roads; one on ten years' progress in vertebrate palæontology; one on mineral wastes and conservation, and a joint session of the zoologists and psychologists on questions relating to animal behaviour. A most important conference on psychology and medical education was held at the Government Hospital, in which eminent psychologists and alienists discussed pertinent questions. The Botanical Section held a symposium on soils, and another on modern aspects of palæobotany. Still another symposium was conducted on acapnia and shock.

The council passed resolutions favouring the establishment of a national quarantine and inspection service directed against the introduction of injurious insects and plant diseases, and others favouring the establishment of a national department of health. Reports of delegates to several international congresses were read.

The general committee selected Cleveland, Ohio, for the place of the next meeting, to open December 30 , I9I2, and recommended to the following general committee that Atlanta, Georgia, be selected for the meeting in the winter of I913-r4. It also expressed the desire that arrangements for a summer meeting during 19 I5 be made.

The following officers for the ensuing year were elected :- President: Dr. E. C. Pickering, director of the Harvard Astronomical Observatory, Cambridge, Mass. Vice-Presidents (or Presidents of Sections): Section A, E. B. Van Vleck, University of Wisconsin, Madison, Wis. ; Section B, A. G. Webster, Clark University, Worcester, Mass.; Section C, W. Lash Miller, Toronto, Canada; Section D, J. A. Holmes, Bureau of Mines, Washington, D.C.; Section E, J.E. Todd, University of Kansas, Lawrence, Kansas; Section F, W. A. Locy, North-Western University, Evanston, Illinois; Section G, D. S. Johnson, Johns Hopkins University, Baltimore, Maryland; Section $\mathrm{H}$, J. Walter Fewkes, Smithsonian Institution, Washing- ton, D.C.; Section I, J. Hays Hammond, New York, N.Y.; Section K, J. J. R. Macleod, Western Reserve Medical College, Cleveland, Ohio; Section L, J. McKeen Cattell, Columbia University, New York, N.Y. Secretaries of Sections: Section B, W. J. Humphreys, U.S. Weather Bureau, Washington, D.C.; Section E, George F. Kay, University of Iowa, Iowa City, Iowa; Section K, Waldemar Koch, University of Chicago, Chicago, Illinois. General Secretary: Henry E. Summers, Iowa State College, Ames, Iowa. Secretary of the Council: H. W. Springsteen, Western Reserve University, Cleveland, Ohio.

The first meteorological gathering in connection with a meeting of the association was held in the Forecast Room of the Weather Bureau on December 28 , the second day of the Washington meeting. As the interval of time between the morning and afternoon sessions of the various sections and societies was too short-and the meeting places were too widely separated-to admit of a "meteorological luncheon," in emulation of the British Association, a "meteorological tea" was decided on as the most practicable and agreeable form of gathering for the interchange of ideas among persons interested in the science of weather. After an hour spent in informal intercourse and an inspection of the buildings and installations of the bureau, five-minute talks were given on the subject, "The Relation of Meteorology to Other Sciences" by Prof. A. Lawrence Rotch ("Aëronautics"), Prof. E. B. Frost ("Astronomy"), Prof. Henry Crew ("Physics"), Prof. W. M. Davis ("Physical Geography"), Prof. W. I. Milham ("Education"). The chief of the Weather Bureau, Prof. Willis Moore, gave the address of welcome, and the speakers were introduced by Prof. W. J. Humphreys.

As a whole, both from the point of view of the attendance and the character of papers read and the general interest shown in the symposia, conferences, and important papers, the meeting undoubtedly will rank as the most important ever held.

The social features of the meeting were of great interest, receptions, dinners, smokers, and visits to the many places of interest in and about Washington more than occupying all the time which could be spared from the sectional meetings. The most notable social function was a reception to the lady visitors at the White House in the afternoon of December 28 .

\section{NOTES.}

ON January 2 I mathematicians of many countries will meet at the Sorbonne to do honour to M. Gaston Darboux on the jubilee anniversary of his entry at the Polytechnic School. As the successor, first of Liouville, and then of Chasles, M. Darboux has added lustre to two famous chairs, and by his published works has earned a reputation of the very first order. To Englishmen he is perhaps best known by his connection with the Bulletin, his researches on cyclides (in conjunction with Casey), and his admirable treatise on the theory of surfaces. The lastnamed work, both in style and method, may be compared with Salmon's classical treatises. Like Salmon, M. Darboux has an equal mastery of geometrical and analytical theories, and combines them with the happiest effect; like him, too, he has the power of drawing material from the most diverse sources, and fusing it into a homogeneous whole. In offering him our congratulations, we feel that we are expressing a sentiment shared by all who are acquainted with M. Darboux's scientific work; and we are sure that they will join with us in hoping that his energy and vigour may be long maintained.

NO. 2203, VOL. 88] 